\title{
Investigating the link between carbon dioxide emissions and transport-related social exclusion in rural Northern Ireland
}

\author{
M. Kamruzzaman $\cdot$ J. Hine $\cdot$ T. Yigitcanlar
}

Received: 18 April 2014/Revised: 8 January 2015/Accepted: 27 January 2015/Published online: 17 February 2015

(C) Islamic Azad University (IAU) 2015

\begin{abstract}
Carbon dioxide $\left(\mathrm{CO}_{2}\right)$ is considered the most harmful of the greenhouse gases. Despite policy efforts, transport is the only sector experiencing an increase in the level of $\mathrm{CO}_{2}$ emissions and thereby possesses a major threat to sustainable development. In contrast, a reduced level of mobility has been associated with an increasing risk of being socially excluded. However, despite being the two key elements in transport policy, little effort has so far been made to investigate the links between $\mathrm{CO}_{2}$ emissions and social exclusion. This research contributes to this gap by analysing data from 157 weekly activity-travel diaries collected in rural Northern Ireland. $\mathrm{CO}_{2}$ emission levels were calculated using average speed models for different modes of transport. Regression analyses were then conducted to identify the socio-spatial patterns associated with these $\mathrm{CO}_{2}$ emissions, mode choice behaviour, and patterns of participation in activities. This research found that despite emitting a higher level of $\mathrm{CO}_{2}$, groups in rural areas possess the risk of being socially excluded due to their higher levels of mobility.
\end{abstract}

Keywords Activity participation - Carbon dioxide $\left(\mathrm{CO}_{2}\right)$ emissions · Northern Ireland · Sustainable transport . Sustainable development . Transport disadvantage . Travel behaviour

M. Kamruzzaman $(\bowtie) \cdot$ T. Yigitcanlar

School of Civil Engineering and the Built Environment, Queensland University of Technology, 2 George Street, Brisbane, QLD 4000, Australia

e-mail: md.kamruzzaman@qut.edu.au

J. Hine

School of the Built Environment, University of Ulster, Shore Road, Newtownabbey, County Antrim BT37 0QB, Northern Ireland, UK

\section{Introduction}

Two policy themes that have featured heavily in UK transport strategy include the reduction in greenhouse gas emissions and the reduction in transport-related social exclusion (Department for Transport 2011; Department of the Environment Transport and the Region 1998). The first theme has been influenced by the need to meet the global policy agenda requirements such as the 1997 Kyoto protocol (Chapman 2007; Loo and Li 2012), whereas the UK has played a leading role in developing policy responses to transport disadvantage and social exclusion (Currie et al. 2009). Despite the intensity of research on both themes, little effort so far has been made to explore the interplay between these two key policy areas (Begg and Gray 2004; Rassafi and Vaziri 2005). An understanding of this relationship is an important first step to the development of future policy responses such as downstream carbon permit trading in the personal road transport sector, which has the potential, for example, to allocate carbon permits without forcing groups/individuals into immobility (Fawcett 2010; Wadud et al. 2008).

According to the Climate Change Act 2008, the UK government is committed to a reduction of $80 \%$ greenhouse gases on the 1990 levels by 2050 (Committee on Climate Change 2008). In addition, it has set three intermediate carbon budgets for 2008-2012, 2013-2017, and 2018-2022, and in May 2011, the coalition government committed the UK to further radical reductions for the fourth budget period 2023-2027. More specific targets have been set for transport sector, which include a $26 \%$ reduction (relative to 2008) by 2020 and $44 \%$ by 2030 (Committee on Climate Change 2010). Carbon dioxide $\left(\mathrm{CO}_{2}\right)$ is considered the most harmful amongst the greenhouse gases (e.g. carbon dioxide, nitrous oxide, water 
vapour, methane) in terms of the contribution to global climate change that would be essentially irreversible (Brand and Preston 2010; Nocera et al. 2012; Simpson 2006; Solomon et al. 2009). Road transport alone produces about $28 \%$ of $\mathrm{CO}_{2}$ in UK (Department for Transport 2010a), and $12 \%$ of global $\mathrm{CO}_{2}$ is produced from the personal road transport sector and is the only sector in which this trend is increasing (Anable et al. 2012; Meyer et al. 2007; Simpson 2006; Wadud et al. 2008). As a result, the reduction in $\mathrm{CO}_{2}$ emissions from the transport sector has been identified as a major challenge to these targets being met (Chapman 2007; Fudge and Peters 2011).

Although the reduction in car use has been highlighted as a means to reduce $\mathrm{CO}_{2}$ emissions from personal travel, the car is considered a lifeline for those living in rural areas due to the declining nature of both public transport services and locally available goods and services (Banister 2008b; Farrington et al. 1998; Gray et al. 2006; Higgs and White 2000; McDonagh 2006; Moseley 1979; Nutley 1985, 1986; Shucksmith and Chapman 1998; Shucksmith and Philip 2000). In Northern Ireland (NI), for example, $78 \%$ of individuals who live in urban areas have a bus stop within 6-min walking distance from their home in comparison with $49 \%$ in rural areas. Only $5 \%$ of individuals have train stations within 26-min walking distance from their home in rural areas, whereas this is $35 \%$ in urban areas (Department for Regional Development 2008). This suggests that rural dwellers are structurally dependent on the car (Ahern and Hine 2012; Howarth and Polyviou 2012; McDonagh 2006; Shergold and Parkhurst 2012). Therefore, the question remains as to what extent any carbon reduction policy will be socially sustainable in rural areas. In addition, despite the contemporaneous nature of the transformative shift to low carbon mobility, very little has been published academically from a socio-economic perspective, with the research literature to date tending to focus on technical challenges and solutions (Berkeley and Jarvis 2012).

This research aims to: first, identify socio-spatial patterns of $\mathrm{CO}_{2}$ emissions in rural areas; second, examine the travel behaviour patterns of low $\mathrm{CO}_{2}$ emitters in order to understand why certain groups emit a lower level of $\mathrm{CO}_{2}$ and why others do not; and third, assess the extent to which any $\mathrm{CO}_{2}$ reduction policies could be implemented without forcing groups into being at risk of social exclusion. This research was conducted in three rural areas of NI (i.e. Doagh, Moira, and Saintfield), using weekly activity-travel diary data collected in 2009-2010 from a representative sample. A detailed review of the literature on the concept of transport-related social exclusion, $\mathrm{CO}_{2}$ emissions reduction policies, and the methods used to measure $\mathrm{CO}_{2}$ emissions is conducted in "Materials and methods" section. It also highlights the methodological limitations associated with measuring the concept of transport-related social exclusion and also the challenges of making assessments of the link between travel choices and the measurements of $\mathrm{CO}_{2}$ emissions. "Methods" section also discusses the methodology used to derive: a) $\mathrm{CO}_{2}$ emission levels from personal travel, based on eight different modes; b) an individual's mode choice behaviour; and c) their level of participation in society (activity patterns). "Results and discussion" section presents the results of such analyses. The impacts of alternative land use patterns in reducing $\mathrm{CO}_{2}$ emission levels were also investigated by selecting three case study areas with differential levels of area accessibility and area mobility options in this research. Based on study findings, "Conclusion" section discusses their implications in policy terms and presents the conclusions from this research.

\section{Materials and methods}

\section{Literature review}

\section{Personal travel and $\mathrm{CO}_{2}$ emissions reduction policies}

A multiplicity of factors can influence the level of $\mathrm{CO}_{2}$ emissions from personal road transport such as fuel efficiency/economy (e.g. kilometres driven per litre), emission standard of fuels (e.g. amount of carbon content within a litre of fuel), travelled distance (e.g. the longer people drive, the more fuel they consume and consequently emit more $\mathrm{CO}_{2}$ ), and chosen mode of transport (e.g. car emits higher per capita emissions compared to public transport). These factors have been classified as technological efficiency (e.g. the first two factors) and human travel behaviour (e.g. the last two factors) categories in the literature (Anable et al. 2012; Ketelaer et al. 2014). Policy efforts to date have sought to target both categories in order to reduce $\mathrm{CO}_{2}$ emissions from road transport.

The European Union considers that the development of new technologies provides the main possibility for reducing transport emissions (Torres and Pinho 2011). Evidence is slowly becoming available that technological efficiency (e.g. new vehicle, fuel economy) has stagnated/slowed down the rate of $\mathrm{CO}_{2}$ emissions in many European and US cities (Schipper 2011). More importantly, technological changes are easy to implement because these are often regulated by national/international bodies (Garren et al. 2011). At the same time, a shift to low carbon mobility presents societal challenges. Policy makers need to ensure that the transformative shift already underway does not exclude sections of society less able to afford new technologies entering the market, particularly in the short to medium term when their cost is high (Berkeley and Jarvis 
2012). Wells (2012) has highlighted that within regions the privileges accorded to those owning and using electric vehicles will further exacerbate mobility disadvantage for those excluded from ownership or use.

Despite the technological improvements, numerous studies have found that $\mathrm{CO}_{2}$ emissions from personal road transport are increasing and which are driven by changes in travel behaviour including high car dependency, declining levels of private car occupancy, increases in per capita trip rates, and longer motorised trip distances (e.g. vehicle kilometres travel-VKT) (Darido et al. 2014; O'Mahony et al. 2012). Consequently, various studies have argued in favour of behavioural shift policy measures indicating that technology has very little to do because an increasing technological efficiency means more people will be attracted to use it and also people will be using it more (Anable et al. 2012; Chapman 2007; Wadud et al. 2008). For example, Kelly et al. (2009) have shown that newer cars produced a higher share of $\mathrm{CO}_{2}$ emissions than older cars in the vehicle fleet in Ireland between 2000 and 2005. Similarly, Marques et al. (2012) have shown that the recent reduction in $\mathrm{CO}_{2}$ emissions through dieselisation has been surpassed by the increased kilometres driven in Europe. Consequently, a growing urgency in policy circles on the need for more effective strategies to reduce carbon emissions has seen the development of a stronger focus on behaviour change in the UK (Fudge and Peters 2011). For example, the UK Government's Community Action 2020-Together We Can encapsulated the increased focus on behaviour change, and in this regard, a Framework for Behaviour Change has also been developed (HM Government 2005). The Department for Environment, Food and Rural Affairs has also published a Pro-Environmental Behaviours Framework in this regard (DEFRA 2008).

Policy interventions aimed at a behavioural shift towards low carbon mobility has been classified into push (e.g. travel behavioural changes by reducing the attractiveness of the car through higher taxes) and pull (e.g. travel behavioural changes by improving the attractiveness of public transport services by lowering fares and designing walkable roads) measures (Yigitcanlar and Kamruzzaman 2014). These measures are again classified as soft or psychological (e.g. campaign, individualised travel planning, teleworking, and car pooling) and hard/structural (i.e. modification in infrastructure or legislation-congestion charging) interventions (Department for Transport 2009). Although the effectiveness of such interventions has been assessed in various contexts, they are sporadic in nature (Avineri and Waygood 2013; Department for Transport 2004, 2009).

Research has shown that following the implementation of a number of soft-policy options in three UK towns between 2004 and 2009, car travel was reduced by $9 \%$ and the use of more sustainable transport options increased substantially-i.e. bus 10-22, cycling 26-30, and walking $10-13 \%$ (Department for Transport 2010b). In addition to these soft measures, research has also highlighted the need for hard (physical) measures such as the allocation of land uses according to the needs of travellers (Frank et al. 2000; Santos et al. 2010). This is due to the fact that travel is a derived demand and the location of available opportunities will shape the demand for travelling (Banister 2008a). However, research findings to date are contradictory in nature. Wang et al. (2014) found that changing urban form between 2000 and 2009 significantly impacted on commuting $\mathrm{CO}_{2}$ emission levels in Beijing. In contrast, Brand and Preston (2010) did not find any significant relationship between $\mathrm{CO}_{2}$ emissions and land use patterns or household locations in the UK context. Little is known about the socio-spatial patterns of $\mathrm{CO}_{2}$ emissions from personal travel and in turn which policy interventions can be targeted to encourage more behavioural change (Anable et al. 2012; Brand and Boardman 2008; Brand and Preston 2010; Frank et al. 2000). This is particularly true in rural areas despite the rate of car use being higher and longer distance trips being made when compared to urban trips ${ }^{1}$ (Department for Regional Development 2008; NISRA 2001). This means that per capita $\mathrm{CO}_{2}$ emissions are much higher in rural areas (Brand et al. 2013), and as a result, rural areas deserve more policy attention in order to meet the stated targets and also to reduce spatial disparities in the $\mathrm{CO}_{2}$ emissions level (Glaeser and Kahn 2010; Tian et al. 2012).

\section{Measures of $\mathrm{CO}_{2}$ emissions from road transport}

The methodology used to calculate $\mathrm{CO}_{2}$ emissions from road transport can broadly be classified into aggregate (topdown) and disaggregate (bottom-up) measures (Garren et al. 2011; Kok et al. 2011; Li 2011). Our review shows that most studies to date have used the aggregate measures in which $\mathrm{CO}_{2}$ emissions from road transport are calculated for a geographic area (e.g. country, state, city, and municipalities). Within aggregate measures, three approaches to estimate $\mathrm{CO}_{2}$ emissions have commonly been used and included: (a) fuel consumption, (b) vehicle registration, and (c) travel distance method (e.g. VKT) (Kennedy 2010). The

\footnotetext{
${ }^{1}$ For instance, the 2012 National Travel Survey data show that $45 \%$ households in London (or $20 \%$ in small/medium towns) have no car, whereas this is only $9 \%$ in rural areas. $52 \%$ of the households in rural areas own two or more cars in comparison with $16 \%$ in London (or $34 \%$ in small/medium towns). In addition, although both urban and rural households made almost an equal number of trips (983 per person per year), $78 \%$ of the trips were made by using the car in rural areas compared to $40 \%$ in London (or $66 \%$ in small/medium towns) and also the average journey length is much higher in rural areas $(9.7$ miles in rural areas versus 4.6 miles in London (or 7.2 miles in small/ medium towns).
} 
fuel consumption method is usually used for larger geographic areas (e.g. nation, state). In this method, total $\mathrm{CO}_{2}$ emissions are calculated based on total sales of fuel (different types) in a geographic area and their associated emission factors. A weakness of this method is the assumption that all fuels sold within a geographic area are also consumed within that area, and therefore, the method may produce a misleading result for smaller geographic areas. As a way forward, the vehicle registration method is used to calculate $\mathrm{CO}_{2}$ emissions for smaller geographic areas (e.g. municipalities). This method, first, calculates the total $\mathrm{CO}_{2}$ emissions for a larger geographic area (e.g. state) using the fuel consumption method. Then, the total emissions are proportionately scaled down based on the percentage of registered vehicles which reside within the smaller areas. The third method calculates $\mathrm{CO}_{2}$ emissions based on total distance travelled (e.g. VKT) by all individuals living in a particular area. This is the most widely used method because of the availability of VKT data for local areas. In this method, the VKT data are used to estimate total fuel consumption based on a nationally averaged fuel economy value for different modes of transport (cars and/or trucks). Total fuel consumption is then converted into a total $\mathrm{CO}_{2}$ emissions level based on the emission factor of specific fuel type.

Andrews (2008) has simplified the VKT method by generating a weighted total fuel economy factor for all modes (e.g. car and light trucks). In this method, the modespecific weights were generated based on modal split (e.g. proportion of trips made by different modes). In addition, this method has not taken into account fuel-specific emission factors for the calculation of $\mathrm{CO}_{2}$ emissions. Some researchers have, however, differentiated total VKT based on nationally averaged driving conditions such as highway driving (45\%) and city driving (55\%). A specific fuel economy is then applied to each condition in order to calculate the total fuel consumption within a geographic area. This uniform differentiation of driving condition for all geographic areas has also been criticised in the literature, particularly in areas with a mismatched share of highways and urban roads. In response, Garren et al. (2011) developed a local condition methodology that takes into account the actual VKTs of urban areas and highway conditions for different areas. In the absence of real VKT data, researchers have also used different modelling techniques (e.g. regression, gravity, simulation) to estimate VKT and consequently $\mathrm{CO}_{2}$ emissions within an area (see, for example, Wang et al. 2014).

Whilst the aggregate approaches are useful for devising top-down policy measures, they provide little evidence on how these measures will impact on individuals who are at risk of being excluded from society due to immobility - an issue that has been far less well researched (Lucas and
Jones 2012). In addition, O'Mahony et al. (2012) have highlighted that an understanding of the factors behind $\mathrm{CO}_{2}$ emissions (why some groups emit more than others) is essential to formulating climate change mitigation policy and the development of applicable targets. As a result, researchers have started using disaggregate measures in order to understand the complexity and patterns of $\mathrm{CO}_{2}$ emissions associated with personal travel. The use of household travel survey data (HTSD) has been identified as the most effective way of modelling the complexity of $\mathrm{CO}_{2}$ emissions in these studies (see Brand and Preston 2010; Darido et al. 2014; Ko et al. 2011; Mathez et al. 2013).

Ko et al. (2011) have identified groups of high $\mathrm{CO}_{2}$ emitters in the Seoul Metropolitan Area using the 2006 HTSD. This work used published emission factor data as used in Japan and calculated $\mathrm{CO}_{2}$ emission levels for passenger car, taxi, bus, and subway. This work reported that the top $10 \%$ of emitters in Seoul were responsible for $63 \%$ of emissions with adult males being the largest emitters in the city $(3.9 \mathrm{~kg} / \mathrm{day})$. Using the characteristics of the last trip made (mode, distance, speed) to McGill University and associated emission factors, Mathez et al. (2013) identified socio-temporal patterns of $\mathrm{CO}_{2}$ emitters. The study then used these identified patterns and generated a number of $\mathrm{CO}_{2}$ emission scenarios (e.g. what if all drivers switch to transit). McNamara and Caulfield (2011) calculated $\mathrm{CO}_{2}$ emissions of commuting trips based on VKT and emission factors by mode in Dublin. This work then examined the impact of introducing a $20 \% \mathrm{CO}_{2}$ reduction cap on national average emissions and identified commuters who are above the cap likely to drive to work over long distances, have dependent children in their household, and own more than one car. Using disaggregate measures, Brand and Preston (2010) found groups that potentially emit a lower level of $\mathrm{CO}_{2}$ include those on low income, are of non-working occupational status, older in age, and without their own cars.

The evidence from above studies shows that a number of factors are important in the calculation of $\mathrm{CO}_{2}$ emissions from personal travel including the choice of travel mode, distance travelled (VKT), carbon content in fuel (e.g. fuel type), fuel economy, driving condition. Despite the development of various models (see Boulter et al. 2007 for a review), most of the disaggregate studies have used the average speed model to calculate $\mathrm{CO}_{2}$ emissions. A number of software tools have also been developed over the years to calculate emission levels based on the average speed models including MEET (Methodologies for Estimating air pollutants Emissions from Transport), COPERT (Computer Programme to Calculate Emissions from Road Transport), NAEI (National Atmospheric Emissions Inventory), and ARTEMIS (Assessment and Reliability of Transport Emission Models and Inventory Systems) (see 
Barlow and Boulter 2009; Ntziachristos and Samaras 2009). Most of the disaggregate studies have, however, overlooked many of the above factors that may potentially contribute to $\mathrm{CO}_{2}$ emissions-probably for the reason of simplification. Research has shown that $\mathrm{CO}_{2}$ emissions can be generated in two different ways from road transport hot exhaust emissions when any vehicle operates at normal temperature and cold start emissions when a vehicle starts after certain period of rest (Boulter et al. 2007; Joumard and Andre 1990; Ntziachristos and Samaras 2009; Tchepel et al. 2012).

\section{Measures of transport-related social exclusion}

Social exclusion is a process, the key outcome of which is a lack of participation in daily activities (Burchardt et al. 1999, 2002). Studies have found evidence which indicates that transport plays a central role in this process as it enables people to reach essential opportunities (Currie and Stanley 2008; Hine and Mitchell 2003; Social Exclusion Unit 2003). Accessibility planning has been advocated as a key policy tool aimed at reducing transport-related social exclusion in the UK (Cass et al. 2005; Currie and Stanley 2008; Department for Transport 2006). A recent study has examined the impacts of different accessibility planning initiatives in the UK and found differential levels of impacts (from providing a "degree of access to basic services" to "life changing") and that has directly contributed to the promotion of social inclusion (Kilby and Smith 2012). Consequently, this study has advocated that "accessibility planning can and should be recognised as key to localism" in the recent changing policy context of accessibility planning (p. 34). Other policy initiatives with a significant impact in reducing transport-related social exclusion are the concessionary fare schemes for younger and older age people (Jones et al. 2013).

An assessment of transport-related social exclusion generally follows a two-step process: first, an identification of transport disadvantaged groups/areas that possess a lower level of accessibility and/or mobility and generally referred to as transport disadvantaged and second, an evaluation of the nature of exclusion or non-participation of the identified disadvantaged groups (Kamruzzaman and Hine 2011). Although some of the studies have used a quantitative technique to identify transport disadvantage, a majority have used qualitative data (e.g. focus groups, interviews) to identify the nature of exclusion or non-participation in activities. As a result, the evidence presented in these studies is inadequate for assessing the relationship between $\mathrm{CO}_{2}$ emissions and social exclusion. Church et al. (2000) have mentioned that in the absence of an objective assessment, qualitative investigation will provide only a limited appreciation of the extent of transport-related social exclusion.

Traditionally used measures to identify transport disadvantage are aggregated in nature such as service deprivation measure within the multiple deprivation-based measures and accessibility planning approach within the many local transport plans in the UK (Department for Communities and Local Government 2008; NISRA 2005; Scottish Executive 2006; Welsh Assembly Government 2008). Despite its usefulness, studies have highlighted a number of weaknesses to this approach in identifying transport disadvantage. Methodology has been identified as one of these barriers, particularly where it has been unable to identify people's actual patterns of travel and participation in activities (Department for Transport 2006; Lucas 2006). The policy challenge therefore relates to the ability to identify those groups and individuals in society who face transport disadvantage in order to address their needs, because both transport and opportunities remain unequal both within and between areas (Hine and Mitchell 2003; Hodge et al. 2002; Knowles 2006). This suggests the need for a more disaggregated approach in the identification of transport disadvantage as well as their non-participation in activities.

Various groups have been identified in the literature that possess the risk of being excluded from society due to their immobility and included low incomes, elderly, unemployed, disabled, women with children, non-car-owning households (Hine and Mitchell 2001; Kamruzzaman and Hine 2011; Social Exclusion Unit 2003). Most of these groups have also been identified as the low $\mathrm{CO}_{2}$ emitters in various geographic contexts. However, most of these studies have been conducted in urban areas. The patterns of transport disadvantage and $\mathrm{CO}_{2}$ emissions could be distinctly different in the context of rural areas. For example, Shergold and Parkhurst (2012) found that car availability is not a strong indicator of overall inclusion in rural England. In contrast, as shown earlier (see footnote 1), car-owning individuals are likely to drive more in rural areas and have different $\mathrm{CO}_{2}$ emission levels. Therefore, a critical assessment is necessary to identify the linkage between $\mathrm{CO}_{2}$ emissions levels and social exclusion in rural areas so that the social impacts and distributional effects of any future policy decision aimed at reducing $\mathrm{CO}_{2}$ emissions can be evaluated (Gough 2013; Lucas and Jones 2012; Wadud et al. 2008; Wells 2012). This issue has clearly been acknowledged in NI which has stated that "sustainable transport may mean different things in urban and rural areas-one policy does not fit all" (Northern Ireland Assembly 2011). 
Methods

Data

The NI government committed to reduce $\mathrm{CO}_{2}$ emissions in order to meet the targets as set out in the UK Climate Change Act 2008 (Northern Ireland Assembly 2011). The government has also recognised that the challenge to sustainable transport is more severe in NI compared to other parts of the UK due to greater levels of rural driving and consequently a relatively higher level of emissions per capita. The Northern Irish government has undertaken a series of policy initiatives aimed at reducing $\mathrm{CO}_{2}$ emissions levels including attitudinal change towards sustainable transport, utilisation of more sustainable transport technologies, investment in public transport, and investment in rural roads. The latter is seen as being important because the government recognises that public transport services are not available at all times, and therefore, the reliance on private car is inevitable. Many of these policy options have also been echoed in other policy documents aimed at reducing transport-related social exclusion in NI (Department for Regional Development 2001, 2002, 2005). The question, however, remains as to what extent these unique policies contribute to $\mathrm{CO}_{2}$ reduction and reductions in transport-related social exclusion. This issue was investigated in this research using individual level activity-travel data collected during the summer of 2009 and 2010 through an activity-travel diary survey from three case study areas located in rural NI: Moira, Saintfield and Doagh (Fig. 1). The three case study areas were selected using differential levels of area accessibility and area mobility criteria:

- Moira: A self-contained village (in terms of locally available opportunities) located within walking distance from the motorway and train station but located away from urban areas.

- Saintfield: A self-contained village located away from the motorway, train station, and urban areas.

- Doagh: Not a self-contained village, located away from the motorway and train station, but located close to urban areas (e.g. Ballyclare).

Respondents for the activity-travel survey were selected from those in the sample who took part in a questionnaire survey conducted in an earlier phase of this research and those who provided consent for their participation in the activity-travel survey. Although 85, 77, and 96 respondents provided consent; 45, 62, and 50 activity-travel diaries were collected from Moira, Saintfield, and Doagh, respectively (an average return rate of $60 \%$ ). Therefore, a total of 157 activity-travel diaries were analysed in this research. Details about sampling, survey design framework, and the representativeness of the sample to the wider population have been published elsewhere and are not discussed here in detail (Hine et al. 2012; Kamruzzaman and Hine 2011). These diaries contained a seven consecutive days of out-of-home travel and the activity details of respondents including trip origin, trip destination, trip start time, trip end time, trip day, trip purpose, travel mode, and roads/routes travelled for 3,057 individual trips. Respondents' socio-economic data were collected through the questionnaire survey and were used as the explanatory variables to identify differences in the levels of $\mathrm{CO}_{2}$ emission, travel behaviour, and activity participation (outcome variables) in this research (Table 1). Due to area accessibility and area mobility differences between the case study areas, an individual living area profile was also used as a spatial explanatory variable (rural form) in this research in order to model contextual influence on the outcomes. Note also that originally the research was designed to investigate transport-related social exclusion in rural NI with no intention to analyse $\mathrm{CO}_{2}$ emissions patterns. Consequently, the datasets do not necessarily contain all the factors to precisely derive $\mathrm{CO}_{2}$ emissions level data. The data in this paper, however, do represent a serious attempt to calculate $\mathrm{CO}_{2}$ emissions and explore the linkages with patterns of travel behaviour.

\section{Calculation of $\mathrm{CO}_{2}$ emissions}

This research derived both hot exhaust and cold start $\mathrm{CO}_{2}$ emissions. The average speed model was used to calculate hot exhaust $\mathrm{CO}_{2}$ emissions level for each trip in this research. An analysis of the collected data shows that individuals used eight different modes in the 7 days surveyed (Table 2). Individuals' reported trip origin, trip destination, and travelled routes were geo-referenced, and consequently, trip distances were derived. Travel time associated with each trip was derived by subtracting trip start time from trip end time. Using the trip distances and travel times, average travel speed $(\mathrm{km} / \mathrm{h})$ for each trip was also derived. Stop over times between trips were calculated by subtracting the trip end time of a trip from the trip start time of the subsequent trip.

Equation 1 was used to calculate hot exhaust $\mathrm{CO}_{2}$ emissions level for each trip (Ntziachristos and Samaras 2009). We have restricted the equation by excluding the engine size and fuel type factors due to limitations in our dataset.

$$
\begin{aligned}
E_{\mathrm{HOT} ; i, j, k, n}(\mathrm{~g})= & e_{\mathrm{HOT}: i, j, k, n}(\mathrm{gm} / \operatorname{mode}-\mathrm{km}) \\
& \times \operatorname{trip} \operatorname{distance}(\mathrm{km})
\end{aligned}
$$

where $E_{\mathrm{HOT}}=$ hot exhaust emissions (in gram) of trip $i$; using transport mode $j$, driving condition $k$, and emission 


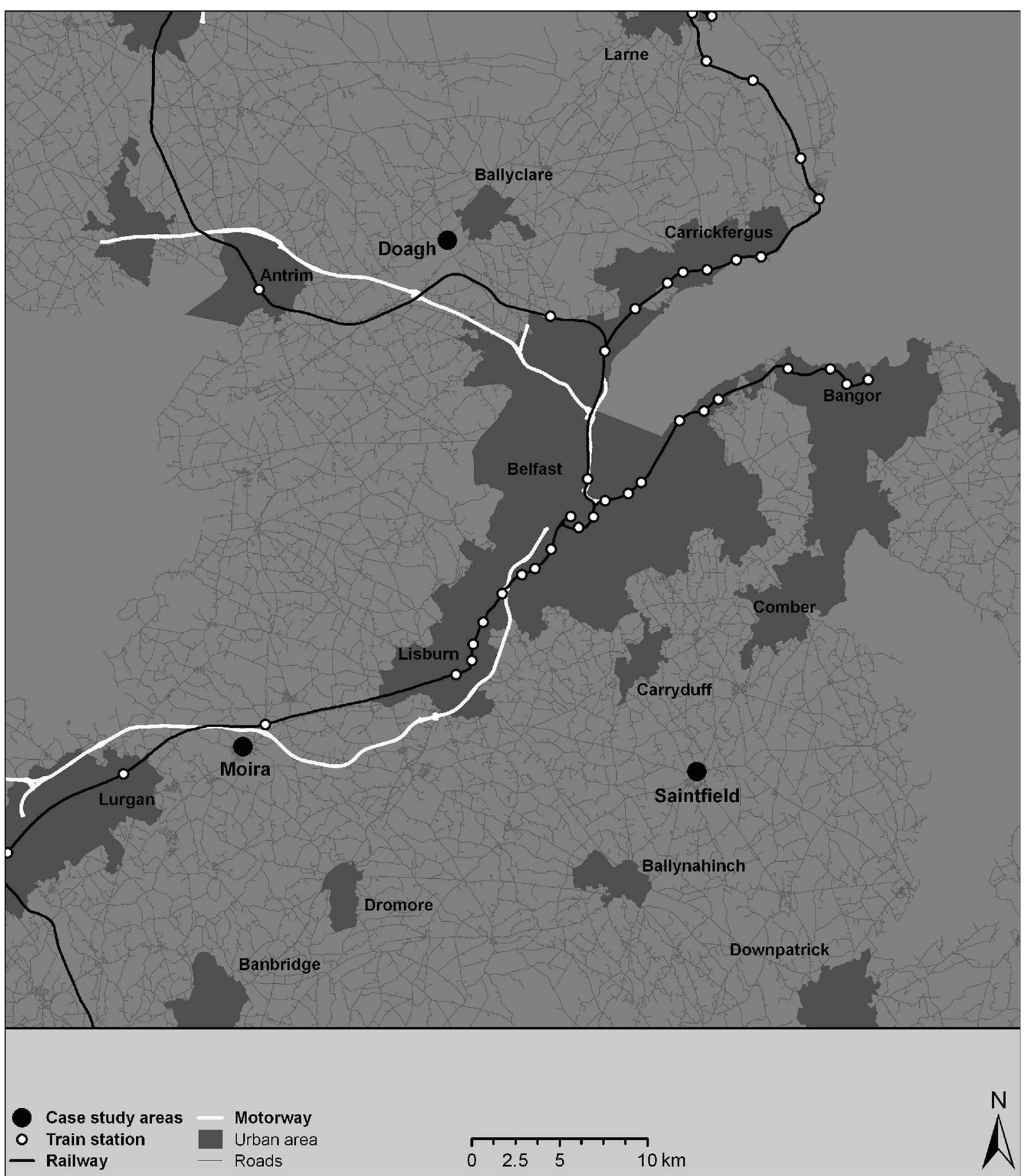

Fig. 1 Location of the case study areas in wider geographic context in Northern Ireland

standard $n$; and $e_{\mathrm{HOT}}=$ associated emission factor under these conditions.

Therefore, $E_{\mathrm{HOT}}$ scores were calculated for each of the 3,057 trips separately. The associated emission factor $\left(e_{\mathrm{HOT}}\right)$ of each trip was selected based on its characteristics (e.g. mode, driving condition) from published sources (Boulter et al. 2009; Brand 2005; Ntziachristos and Samaras 2009). The driving conditions of each trip made by respondents were classified into either urban, or rural, or motorway based on the derived average speed of that trip. ${ }^{2}$ The associated emission factors for bus trips were divided by 10 - given that the average occupancy of

\footnotetext{
$\overline{{ }^{2} \text { Urban }<40} \mathrm{~km} / \mathrm{h}, 40 \mathrm{~km} / \mathrm{h} \leq$ rural $<77 \mathrm{~km} / \mathrm{h}$, motorway $>77 \mathrm{~km} / \mathrm{h}$. These standards were also found to be consistent with the speed limit proposed in the different types of road networks in Northern Ireland.
} 
Table 1 Variables used in the empirical modelling and their definitions

\begin{tabular}{|c|c|c|c|}
\hline Variable names & Coded categories and definition & $\begin{array}{l}\text { Variable used as in the } \\
\text { model }\end{array}$ & $\begin{array}{l}\text { Statistical model used for } \\
\text { analysis }\end{array}$ \\
\hline Area profile & $\begin{array}{l}1=\text { Moira (good area accessibility and area mobility options); } \\
2=\text { Saintfield (good area accessibility and poor area } \\
\text { mobility); } \\
3 \text { = Doagh (poor area accessibility and poor area mobility) }\end{array}$ & Explanatory & - \\
\hline Gender & $\begin{array}{l}1=\text { Male } \\
2=\text { Female }\end{array}$ & Explanatory & - \\
\hline No. of car & Number of car in household & Explanatory & - \\
\hline Income & $\begin{array}{l}1=\text { Low income (income level below the average income of } \\
\text { rural NI); } \\
2=\text { High income (income level above the average income of } \\
\text { rural } \mathrm{NI} \text { ) }\end{array}$ & Explanatory & - \\
\hline Age & $\begin{array}{l}1=\text { Young }(18-59 \text { years }) \\
2=\text { Older }(60 \text { years and above })\end{array}$ & Explanatory & - \\
\hline Occupation & $\begin{array}{l}1=\text { Working (full/part time employed, business) } \\
2=\text { Non-working (retired, unemployed, household } \\
\text { management, student) }\end{array}$ & Explanatory & - \\
\hline Home ownership & $\begin{array}{l}1=\text { Household owning a house; } \\
2=\text { otherwise }\end{array}$ & Explanatory & - \\
\hline $\mathrm{CO}_{2}$ emission & Continuous data type measured by gram $(\mathrm{g})$ in a week & Dependent & General linear model \\
\hline $\begin{array}{l}\text { Mode choice } \\
\text { behaviour }\end{array}$ & Number of trips made using different modes of transport & Dependent & Multinomial logit model \\
\hline $\begin{array}{l}\text { Activity } \\
\text { participation }\end{array}$ & Number of trips made to perform different activities & Dependent & Multinomial logit model \\
\hline
\end{tabular}

rural transport services (Ulsterbus) in NI is 10 people $^{3}$ (Department for Regional Development 2008, 2010). Equation 1 was, however, not used for the calculation of $\mathrm{CO}_{2}$ emissions level associated with the train trips. There are no light rail, electric rail, and tram services operational in NI. The only form of train that is operational in NI is the regional train powered by diesel. As a result, the emission levels from the train trips were calculated using $73.7 \mathrm{~g} /$ passenger-km as an emission factor (Brand 2005). The hot exhaust emission level was considered as zero (0) when trips were made using the bicycle or foot because these modes do not produce any tailpipe emissions (Santos et al. 2010).

Cold start $\mathrm{CO}_{2}$ emissions were calculated only for trips undertaken by using the car. Car trips that were made after 60 min stop over time between the trips were considered as a cold start trip (Frank et al. 2000). The fraction of trip

\footnotetext{
3 This occupancy figure was calculated for the survey period. In 2009-2010, 41.9 million passenger journeys were made using the Ulsterbus services. Total bus-kilometres figure stood at 58.1 million. The Northern Ireland Travel Survey data show that the average journey length using the Ulsterbus services is $13.4 \mathrm{~km}$ ( 8.3 miles). Therefore, the calculated passenger-kilometres for this period is 578.22 million $(41.9 \times 13.4)$. Bus occupancy $=10$ (i.e. passenger$\mathrm{km} / \mathrm{bus}-\mathrm{km})$.
}

length that was made under cold engine conditions was calculated using Eq. 2 (Brand 2005).

$\beta=0.6474-0.02545 \times l_{\text {trip }}-(0.00974-0.000385) \times t_{\mathrm{a}}$

where $\beta=$ fraction of trip length travelled under cold start condition, $l_{\text {trip }}=$ average length of trips under consideration, and $t_{\mathrm{a}}=$ average ambient temperature. The average trip length of all cold start trips using the car was calculated, and it was found to be $15 \mathrm{~km}$ in this research.

Table 2 Descriptive statistics showing the trip characteristics of the data

\begin{tabular}{lrrl}
\hline Mode & $\begin{array}{l}\text { Number of } \\
\text { trips }\end{array}$ & $\begin{array}{l}\text { \% of total } \\
\text { trips }\end{array}$ & $\begin{array}{l}\text { Average trip length } \\
(\mathrm{km})\end{array}$ \\
\hline Driving car & 2,002 & 65.5 & 14.41 \\
Bus & 168 & 5.5 & 15.73 \\
Train & 12 & 0.4 & 29.02 \\
Lift & 208 & 6.8 & 13.30 \\
Walk & 610 & 20.0 & 0.71 \\
Taxi & 35 & 1.1 & 14.95 \\
Bicycle & 20 & 0.7 & 10.94 \\
Motorcycle & 2 & 0.1 & 16.99 \\
Total & 3,057 & 100.0 & 11.71 \\
\hline
\end{tabular}


As mentioned earlier, the activity-travel diaries were collected during the summer and the average temperature in NI varies between 11 and $18{ }^{\circ} \mathrm{C}$ in the survey period (BBC 2010). Therefore, $15^{\circ} \mathrm{C}$ was used as a value for $t_{\mathrm{a}}$ in this research. Using the derived value for $\beta$ coefficient, the cold start emission level was calculated for each trip using Eq. 3 (Brand 2005).

$E_{\mathrm{COLD} ; i}=\beta \times E_{\mathrm{HOT} ; i} \times\left(e^{\mathrm{COLD}} / e^{\mathrm{HOT}}-1\right)$

where $E_{\mathrm{COLD} ; i}=$ cold start emissions (in gram) for trip $i ; \beta$ and $E_{\mathrm{HOT} ; i}$ as above; and $e^{\mathrm{COLD}} / e^{\mathrm{HOT}}=\mathrm{cold} /$ hot emission quotient which was calculated using Eq. 4 (Ntziachristos and Samaras 2009).

$e^{\mathrm{COLD}} / e^{\mathrm{HOT}}=1.9-0.03 \times t_{\mathrm{a}}$

The cold start emission and hot exhaust emission levels were aggregated to derive total emissions associated with each trip. This emission level was further aggregated for each person to derive individual level weekly $\mathrm{CO}_{2}$ emission level data. Using these scores as a dependent variable, a seven factor ANOVA with a full factorial interaction between the explanatory variables was conducted based on the general linear model (GLM) in SPSS in order to identify patterns of $\mathrm{CO}_{2}$ emissions for different socio-spatial groups.

\section{Generating activity-travel patterns}

As the policy emphasis has been placed on behavioural change and the choice of transport mode in order to reduce the $\mathrm{CO}_{2}$ emission levels, this research analyses the mode choice behaviour of different groups in order to understand why certain groups emit a higher level of $\mathrm{CO}_{2}$, whereas others do not. In addition, as a lack of participation in activities has been identified as the key outcome of the social exclusionary process, individual activity patterns were also analysed to identify whether the low $\mathrm{CO}_{2}$ emitters possess the risk of being excluded from society. In transport terms, such participation implies the proportion of trips made to participate in different activities compared to other groups. However, train trips and trips that were undertaken using the motorcycle were excluded from this analysis. This is due to the fact that the train was not available to respondents living in Doagh and Saintfield. Whilst none of the respondents living in Moira and Doagh used the motorcycle as a mode of transport.

A coding list of 29 trip purposes was provided to the respondents participating in the activity diary phase of the research. These trip categories were subsequently grouped into eight main categories: work, social, shopping, recreational, health, food, returning home, and other (e.g. to drop off) for this research. However, return home trips were excluded from this analysis, which is due to the fact that social inclusion means the ability to participate in outof-home activity. As a result, a total of 1,704 individual trips were analysed which finished at locations other than the home (1,353 return home trips). Two multinomial logit models were estimated in STATA: one to identify mode choice behaviour, and the other to identify the rate of participation in different activities. The models computed the relative risk ratios (RRRs) for each explanatory variable that indicated a measure of how much more likely one group (e.g. male) used a certain mode of transport (e.g. bus) (or participated in an activity e.g. social) against the reference category (e.g. car/work) when compared to its counterpart (e.g. female).

\section{Results and discussion}

Socio-spatial patterns of $\mathrm{CO}_{2}$ emitters

Table 3 shows that on average each individual emitted $32 \mathrm{~kg} \mathrm{CO} \mathrm{CO}_{2}$ in a week. No other comparable data are available to verify this level of $\mathrm{CO}_{2}$ emissions in a rural context. In addition, previously reported data are also not consistent across urban areas. For example, Ko et al. (2011) have reported that on average, each person emits about $1.6 \mathrm{~kg} \mathrm{CO}$ a day in Seoul. In contrast, this level of $\mathrm{CO}_{2}$ emission was reported for a single trip to McGill University for different groups (Mathez et al. 2013). Our weekly finding was found to be slightly higher than the previously reported rates, which suggests that people in rural areas emit more $\mathrm{CO}_{2}$ per capita.

A significant model emerged from the GLM test using the weekly $\mathrm{CO}_{2}$ emission level as a dependent variable with good explanatory power (Table 4) (Xing et al. 2010). This means that a significant difference exists in the levels of $\mathrm{CO}_{2}$ emissions between the different groups considered. Area profile, car ownership and occupation variables were found to have a significant effect in the model (Table 4). The post hoc analysis using the area profile variable shows that individuals living in Doagh emitted a significantly higher level of $\mathrm{CO}_{2}(39 \mathrm{~kg})$ compared to individuals living in Moira (37 kg) and Saintfield (23 kg) (Table 3). There could be a number of possible explanations for these differences. For instance: (1) individuals living in Doagh travelled mostly by car. The emission factor associated with the car is higher per passenger kilometre and as a result, despite travelling a shorter distance, this mode could represent a group which is a higher emitter; (2) despite no differences in the mode choice behaviour between the case study areas, individuals living in Doagh travelled longer distances; (3) individuals living in Doagh travelled shorter distances but participated in activities more frequently than 
Table 3 Levels of $\mathrm{CO}_{2}$ emission ( $\mathrm{g}$ ) by different groups in a week

\begin{tabular}{|c|c|c|c|c|c|c|c|c|c|c|}
\hline \multirow[t]{2}{*}{ Variables } & \multirow[t]{2}{*}{ Categories } & \multicolumn{3}{|c|}{ All areas } & \multicolumn{2}{|c|}{ Moira } & \multicolumn{2}{|c|}{ Saintfield } & \multicolumn{2}{|c|}{ Doagh } \\
\hline & & $N$ & Mean & $\%$ change from reference & $N$ & Mean & $N$ & Mean & $N$ & Mean \\
\hline \multirow[t]{3}{*}{ Area profile } & Moira & 45 & $36,834.96$ & Reference & - & - & - & - & - & - \\
\hline & Saintfield & 62 & $23,190.39$ & -37.04 & - & - & - & - & - & - \\
\hline & Doagh & 50 & $39,278.88$ & 6.63 & - & - & - & - & - & - \\
\hline \multirow[t]{2}{*}{ Gender } & Male & 71 & $31,157.99$ & Reference & 18 & $38,477.03$ & 29 & $18,949.44$ & 24 & $40,420.71$ \\
\hline & Female & 86 & $33,105.86$ & 6.25 & 27 & $35,740.24$ & 33 & $26,917.29$ & 26 & $38,224.88$ \\
\hline \multirow[t]{2}{*}{ Car ownership } & Non-car-owning & 24 & $15,819.70$ & Reference & 7 & $16,347.16$ & 11 & $17,292.79$ & 6 & $12,503.67$ \\
\hline & Car owning & 133 & $35,185.33$ & 122.41 & 38 & $40,609.03$ & 51 & $24,462.43$ & 44 & $42,930.04$ \\
\hline \multirow[t]{2}{*}{ Income } & Low income & 88 & $31,200.73$ & Reference & 30 & $36,177.31$ & 30 & $23,502.34$ & 28 & $34,116.96$ \\
\hline & High income & 69 & $33,531.26$ & 7.46 & 15 & $38,150.25$ & 32 & $22,897.95$ & 22 & $45,848.59$ \\
\hline \multirow[t]{2}{*}{ Occupation } & Working & 91 & $32,892.43$ & Reference & 28 & $39,259.04$ & 35 & $25,544.45$ & 28 & $35,710.80$ \\
\hline & Non-working & 66 & $31,304.70$ & -4.823 & 17 & $32,842.36$ & 27 & $20,138.84$ & 22 & $43,820.07$ \\
\hline \multirow[t]{2}{*}{ Age } & Young & 95 & $32,958.21$ & Reference & 24 & $35,802.08$ & 45 & $25,825.39$ & 26 & $42,678.38$ \\
\hline & Older & 62 & $31,101.47$ & -5.63 & 21 & $38,015.39$ & 17 & $16,215.41$ & 24 & $35,596.09$ \\
\hline \multirow[t]{2}{*}{ Home ownership } & Owner & 119 & $32,692.79$ & Reference & 32 & $40,630.91$ & 45 & $21,846.54$ & 42 & $38,265.67$ \\
\hline & Rented & 38 & $30,759.99$ & -5.91 & 13 & $27,491.07$ & 17 & $26,747.65$ & 8 & $44,598.22$ \\
\hline Total & & 157 & $32,224.98$ & & 45 & $36,834.96$ & 62 & $23,190.39$ & 50 & $39,278.88$ \\
\hline
\end{tabular}

Table 4 GLM test results showing the variations in the levels of weekly emission of $\mathrm{CO}_{2}$

\begin{tabular}{lrl}
\hline Source & \multicolumn{1}{l}{ Partial Eta squared } \\
\hline Corrected model & $2.251^{\mathrm{a}}$ & 0.623 \\
Intercept & $173.846^{\mathrm{a}}$ & 0.659 \\
Area profile & $2.781^{\mathrm{a}}$ & 0.058 \\
Gender & 0.642 & 0.007 \\
Car ownership & $14.231^{\mathrm{a}}$ & 0.137 \\
Income & 0.197 & 0.002 \\
Occupation & $6.536^{\mathrm{a}}$ & 0.068 \\
Age & 0.007 & 0.000 \\
Home ownership & 0.753 & 0.008 \\
Interactions & & \\
Area profile $\times$ occupation & $4.281^{\mathrm{a}}$ & 0.087 \\
Income $\times$ age & $4.125^{\mathrm{a}}$ & 0.044 \\
Area profile $\times$ gender $\times$ income & $6.643^{\mathrm{a}}$ & 0.069 \\
\hline
\end{tabular}

${ }^{a}$ Coefficients are significant at the 0.05 level

the other spatial groups; and (4) any combination of these. Therefore, it is clear that the causes of $\mathrm{CO}_{2}$ emissions cannot be explained by only looking at the explanatory factors, but that they need to be analysed along with mode choice behaviour and trip patterns. For that reason, findings from this section are elaborated on further in the next sections of the paper.

Consistent with other studies (Druckman and Jackson 2008), Table 3 also shows that car-owning individuals emitted a significantly higher level of $\mathrm{CO}_{2}(35 \mathrm{~kg})$ compared to their non-car-owning counterparts $(16 \mathrm{~kg})$ in a week. This difference clearly reflects the high levels of car dependency in rural areas and also signifies the potential for the reduction in $\mathrm{CO}_{2}$ if appropriate policy measures are introduced. Individuals who were in employment also emitted a significantly higher amount of $\mathrm{CO}_{2}(33 \mathrm{~kg})$ compared to their non-working counterparts $(31 \mathrm{~kg})$. This is surprising given that non-working individuals had more available time to travel. However, disaggregation of the data found that this was only in the case of Moira and Saintfield. The interaction between area profile and occupation variables was found to have a significant effect in the model, further analysis shows that non-working individuals living in Doagh emitted a significantly higher amount of $\mathrm{CO}_{2}(44 \mathrm{~kg})$ than their working counterpart $(36 \mathrm{~kg})$. Therefore, it appears that despite Moira and Saintfield having more opportunities locally, these settlements are inadequate for facilitating employment opportunities and as a result, individuals living in these areas travel to other urban centres. In Doagh, on the other hand, where individuals are living closer to urban areas have shorter commuting distances. However, since Moira and Saintfield provide a basic level of opportunity, non-working individuals were perhaps able to meet their requirements locally as opposed to those non-working individuals living in Doagh.

Although the main effects of the income and age variables are not significant in the model, the interaction of these two variables was found to have a significant impact in the model. Analysis shows that low-income young 
individuals emitted more $\mathrm{CO}_{2}(33 \mathrm{~kg})$ than their low-income older counterparts $(30 \mathrm{~kg})$ in a week. On the other hand, older individuals with a higher level of income emitted a higher amount of $\mathrm{CO}_{2}(34 \mathrm{~kg})$ than high-income individuals who were younger $(33 \mathrm{~kg})$. An analysis of the interaction between area profile, gender, and income variables indicates that high-income males living in Saintfield emitted a significantly lower level of $\mathrm{CO}_{2}(16 \mathrm{~kg})$ than any other combinations of factors. Analysis shows that highincome males living in Saintfield also tended to have more business locally. As a result, this group rarely travelled outside of their areas. However, high-income females living in Doagh emitted a significantly higher amount of $\mathrm{CO}_{2}$ $(48 \mathrm{~kg})$ than other groups.

In summary, this analysis shows that groups which have a lower level of $\mathrm{CO}_{2}$ emission in rural areas include: (1) an area with a higher level of area accessibility and mobility options, non-car-owning individuals, non-working individuals, low-income and older people, and high-income and younger age groups; and (2) high-income males living in an area with a higher level of accessibility. However, this section raised more questions in terms of the travel behaviour patterns of these low $\mathrm{CO}_{2}$ groups. An attempt was made to answer these questions by analysing the mode choice behaviour of these groups in the following section.

\section{Mode choice behaviour}

This section investigates the mode choice patterns of those groups identified as having a lower level of $\mathrm{CO}_{2}$ emissions. It is clear from Table 5 that individuals who live in an area with a lower level of area accessibility and mobility options (e.g. Doagh) were less likely to use the bus (4 times), take lifts (3 times), walk (5 times), and cycle (4 times) than when compared to their car use. Table 5 also shows that car-owning individuals relied mostly on the car for making all types of trips. As a result, their associated RRRs were found to be significantly reduced for making trips using the bus (20 times), taking lifts ( 2 times) (lower emissions on the grounds of occupancy), using the taxi (2 times) (lower emissions on the basis of no cold start emissions associated with this mode), and walk/cycle (3 times) (zero $\mathrm{CO}_{2}$ emissions) when compared to their non-car-owning counterparts. In a similar way, high-income individuals were significantly less likely to make trips using the bus (5 times), take lifts (2.5 times), and walk (2 times) when compared to their car usage. Older individuals were found to be more likely to make trips using the bus (1.8 times) and on foot (1.5 times). Unlike older individuals, nonworking individuals were found to be less likely to use the bus ( 3 times) and active transport ( 2 times). Note, however, that this group was identified as low-emitters despite not using more sustainable mode of transport. The finding implies that although working individuals used more sustainable modes of transport, they had to participate in their activities more frequently than their non-working counterparts. In addition, on average, work trip length was found to be the longest $(16.9 \mathrm{~km})$ amongst the different activity categories in this research. As a result, the aggregated level of emissions over a week increased significantly for working individuals. The above analysis clearly reflects the location of available opportunities and the choice of transport mode acts as a major factor in reducing the level of $\mathrm{CO}_{2}$ emissions. These findings are

Table 5 Multinomial logistic regression analyses results showing the RRRs of mode choice for different groups

\begin{tabular}{|c|c|c|c|c|c|}
\hline \multirow[t]{2}{*}{ Explanatory variables } & \multicolumn{5}{|c|}{ Dependent variables: chosen transport modes (reference: car) } \\
\hline & Bus & Lift & Taxi & Walk & Bicycle \\
\hline \multicolumn{6}{|l|}{ Area profile (ref: Moira) } \\
\hline Saintfield & $3.32^{\mathrm{a}}$ & $2.76^{\mathrm{a}}$ & 2.24 & $2.50^{\mathrm{a}}$ & 1.95 \\
\hline Doagh & $0.29^{\mathrm{a}}$ & $0.378^{\mathrm{a}}$ & 0.45 & $0.20^{\mathrm{a}}$ & $0.31^{\mathrm{a}}$ \\
\hline Gender: female (ref: male) & 1.22 & $1.61^{\mathrm{a}}$ & 1.31 & $1.24^{\mathrm{a}}$ & $0.14^{\mathrm{a}}$ \\
\hline Number of cars in household & $0.05^{\mathrm{a}}$ & $0.45^{\mathrm{a}}$ & $0.02^{\mathrm{a}}$ & $0.37^{\mathrm{a}}$ & $0.45^{\mathrm{a}}$ \\
\hline Income: high (ref: low) & $0.22^{\mathrm{a}}$ & $0.40^{\mathrm{a}}$ & 1.93 & $0.61^{\mathrm{a}}$ & 1.53 \\
\hline Age: older (ref: young) & $1.80^{\mathrm{a}}$ & 1.08 & 0.86 & $1.56^{\mathrm{a}}$ & 1.43 \\
\hline Occupation: non-working (ref: working) & $0.31^{\mathrm{a}}$ & 0.99 & 1.87 & $0.64^{\mathrm{a}}$ & 0.53 \\
\hline Home ownership: rented (ref: owner) & $0.30^{\mathrm{a}}$ & 0.81 & 0.82 & 0.99 & 1.49 \\
\hline Log likelihood & & & & & $-2,520.30$ \\
\hline LR Chi ${ }^{2}$ & & & & & $1,210.88^{\mathrm{a}}$ \\
\hline Pseudo- $R^{2}$ & & & & & 0.19 \\
\hline$N$ (number of trips made using different modes) & & & & & 3,043 \\
\hline
\end{tabular}

${ }^{a}$ Coefficients are significant at the 0.05 level 
Table 6 Multinomial logistic regression analyses results showing the RRRs of activity participation for different groups

\begin{tabular}{|c|c|c|c|c|c|c|}
\hline \multirow[t]{2}{*}{ Explanatory variables } & \multicolumn{6}{|c|}{ Dependent variables: types of activity participated in (reference: work) } \\
\hline & Social & Recreation & Shopping & Taking a meal & Other & Health \\
\hline \multicolumn{7}{|l|}{ Area profile (ref: Moira) } \\
\hline Saintfield & 0.90 & $0.60^{\mathrm{a}}$ & 0.78 & 1.47 & $1.90^{\mathrm{a}}$ & 0.83 \\
\hline Doagh & 0.97 & 0.82 & 0.81 & $0.37^{\mathrm{a}}$ & $1.75^{\mathrm{a}}$ & $0.29^{\mathrm{a}}$ \\
\hline Gender: female (ref: male) & 1.24 & 1.29 & $1.32^{\mathrm{a}}$ & 1.12 & $3.70^{\mathrm{a}}$ & $1.79^{\mathrm{a}}$ \\
\hline Number of cars in household & $0.78^{\mathrm{a}}$ & 0.96 & $0.78^{\mathrm{a}}$ & 0.95 & $0.82^{\mathrm{a}}$ & $0.67^{\mathrm{a}}$ \\
\hline Income: high (ref: low) & $1.43^{\mathrm{a}}$ & $2.26^{\mathrm{a}}$ & $1.40^{\mathrm{a}}$ & 1.15 & $1.46^{\mathrm{a}}$ & 1.62 \\
\hline Age: older (ref: young) & 1.08 & 1.16 & 1.13 & 0.53 & 0.70 & 0.78 \\
\hline Occupation: non-working (ref: working) & $48.08^{\mathrm{a}}$ & $45.74^{\mathrm{a}}$ & $42.61^{\mathrm{a}}$ & $70.12^{\mathrm{a}}$ & $56.11^{\mathrm{a}}$ & $64.10^{\mathrm{a}}$ \\
\hline Home ownership: rented (ref: owner) & 0.91 & 0.81 & 0.90 & 1.13 & 0.99 & 0.77 \\
\hline Log likelihood & & & & & & $-2,693.38$ \\
\hline LR Chi ${ }^{2}$ & & & & & & $643.47^{\mathrm{a}}$ \\
\hline Pseudo- $R^{2}$ & & & & & & 0.11 \\
\hline$N$ (number of different types of activity participated in) & & & & & & 1,704 \\
\hline
\end{tabular}

${ }^{a}$ Coefficients are significant at the 0.05 level

consistent with the policy initiatives of the government as discussed earlier. However, questions still remain as to whether these low $\mathrm{CO}_{2}$ emitter groups are able to participate in activities as much as those groups who are high $\mathrm{CO}_{2}$ emitters.

\section{Activity patterns}

Table 6 shows that despite being a high producer of $\mathrm{CO}_{2}$, individuals living in Doagh were not able to participate in activities as much as individuals living in Moira and Saintfield particularly for dining out and health-related activities (a 3 times lower participation rate). However, individuals living in Saintfield were found to lack the ability to participate in recreational activities when compared to individuals living in Moira (around a 2 times lower participation rate). Table 6 also shows that the RRRs of making other types of trip (e.g. to drop off, to pick up) were doubled when individuals were found to live in Saintfield and Doagh compared to those respondents residing in Moira. These findings therefore indicate the need for the development of area-based policy interventions through the provision of local goods and services in order to keep the emission level lower in rural areas. Although the non-car group was identified as having a lower level of $\mathrm{CO}_{2}$ emission, Table 6 shows that a higher level of car ownership at household significantly reduced the level of participation in some type of activities (e.g. social, shopping). In contrast, individuals were more likely to participate in different types of activities when the income level is increased. Despite working individuals emitting a significantly higher level of $\mathrm{CO}_{2}$, they were found to be less likely to participate in different types of activities.
These findings, therefore, clearly produce evidence to suggest that individuals do not necessarily need to be high polluters in order to be socially included.

\section{Conclusion}

Excessive emission of $\mathrm{CO}_{2}$ is a global threat (Chapman 2007). Despite a high level of policy concern, there are increases in the level of $\mathrm{CO}_{2}$ emissions from road transport (Anable et al. 2012), which jeopardises realisation of the sustainable development policy goal. As a result, an identification of strategies that could reduce $\mathrm{CO}_{2}$ emissions from road transport is a critical policy challenge worldwide. Researchers have agreed that policy interventions influencing a behavioural shift from carbased travel to more sustainable transport options would be a way forward in addition to improving the technological efficiency of the vehicles/fuel used for personal travel (Anable et al. 2012; Chapman 2007; Kelly et al. 2009). However, very little is known about the $\mathrm{CO}_{2}$ emission behaviour in rural areas despite $\mathrm{CO}_{2}$ emissions per head of population being higher in rural areas than in urban areas (Brand et al. 2013). This research has contributed to this knowledge gap in the literature. It has calculated $\mathrm{CO}_{2}$ emission levels of individuals living in three rural areas in NI using their weekly activity-travel diary data. This research has also investigated the travel behaviour of these individuals to help understand why certain groups emit a lower level of $\mathrm{CO}_{2}$ than others. This research then goes on to evaluate whether a lower level of $\mathrm{CO}_{2}$ emissions results in a lower level of participation in activities. 
Evidence from this research clearly indicates that there is a need for hard policy intervention measures such as encouraging the provision of local opportunities in order to encourage and underpin behavioural changes in travel behaviour in rural areas (Santos et al. 2010). For instance, individuals living in Moira and Saintfield were found to be more likely to make trips on foot due a higher level of area accessibility option. On the other hand, these individuals were also found to make more trips using the bus due to a higher level of area mobility options. As a result, their levels of $\mathrm{CO}_{2}$ emission were found to be significantly lower than those living in an area with a lower level of area accessibility and area mobility options (e.g. Doagh). Although this finding runs against the findings reported by Brand and Preston (2010) in the context of UK, this finding is, however, similar to that reported by other researchers (Frank et al. 2000; Santos et al. 2010; Wang et al. 2014). Therefore, the decline in local services (both in public transport and local goods and services opportunities) in rural areas needs to be reversed even though it may require a greater subsidy (Banister 2008b; Higgs and White 2000; McDonagh 2006). The findings of this research, however, also demonstrate that rural people like to use local services if they are available, which would suggest that a temporary subsidised service can achieve financial viability in the long run (Department for Transport and Greater Manchester Passenger Transport Executive 2004).

This research has found that despite using sustainable transport options (e.g. bus), certain groups (e.g. working individuals) may emit a significantly higher level of $\mathrm{CO}_{2}$ in rural areas particularly when their activity locations are in more dispersed places. Promotion of alternative soft measures such as teleworking, therefore, has a greater role to play in reducing $\mathrm{CO}_{2}$ emissions in rural areas together with the physical measures for some jobs (Banister 2008a; Santos et al. 2010). Evidence in this research shows that although certain groups emitted a higher amount of $\mathrm{CO}_{2}$, their level of participation in society is significantly lower than their counterparts (e.g. working individuals, individuals living an area with a lower level of accessibility and mobility). This means that these groups were excluded from society due to their higher level of mobility (Cass et al. 2005). These groups spent a considerably larger amount of time travelling which they otherwise could have spent in their local neighbourhoods if both soft and physical measures were implemented. A significantly higher level of $\mathrm{CO}_{2}$ emission from the car-owning group was found to exist mainly due to the existence of these travelling patterns. This group was more likely to use the car for making their journeys although their participation in society was found to be significantly lower when compared to their counterparts using other modes.
Sustainable development is a well-recognised concept in today's society, which highlights the need to integrate economic, environmental, and social dimensions within development and policy. In this paper, two of the dimensions (e.g. social and environmental) were jointly investigated with an aim to understand whether one dimension is detrimental to the other in the transport sector. The findings of this research clearly show that these two dimensions are not necessarily conflicting at all; rather the sustainability in one dimension can enhance the sustainability in other dimension (e.g. a shorter travel distance is associated with both a reduction in $\mathrm{CO}_{2}$ emissions and a higher level of participation in society). However, to achieve this, transport policies need to incorporate both soft (e.g. travel demand management) and hard (e.g. the arrangement of land uses to foster walking and cycling, transit oriented development) interventions.

Acknowledgments We acknowledge and cordially thank the Editor-in-Chief and the two anonymous reviewers for their constructive comments and insightful suggestions, which helped us to improve the manuscript.

\section{References}

Ahern A, Hine J (2012) Rural transport-valuing the mobility of older people. Res Transp Econ 34:27-34

Anable J, Brand C, Tran M, Eyre N (2012) Modelling transport energy demand: a socio-technical approach. Energy Policy $41: 125-138$

Andrews CJ (2008) Greenhouse gas emissions along the rural-urban gradient. J Environ Plan Manag 51:847-870

Avineri E, Waygood ODE (2013) Applying valence framing to enhance the effect of information on transport-related carbon dioxide emissions. Trans Res Part A Policy Pract 48:31-38

Banister D (2008a) The sustainable mobility paradigm. Transp Policy 15:73-80

Banister D (2008b) Rural accessibilities and mobilities. In: Becker U, Böhmer J, Gerike R (eds) How to define and measure access and need satisfaction in transport. Dresdner Institut für Verkehr und Umwelt e.V. (DIVU), Dresden, pp 165-178

Barlow TJ, Boulter PG (2009) Emission factors 2009: Report 2-a review of the average-spped approach for estimating hot exhaust emissions. TRL Limited, Wokingham

BBC (2010) Weather: average condition-Northern Ireland. http:// www.bbc.co.uk/weather/world/city_guides/results.shtml?tt= TT003750. 23 Nov 2010

Begg D, Gray D (2004) Transport policy and vehicle emission objectives in the UK: is the marriage between transport and environment policy over? Environ Sci Policy 7:155-163

Berkeley N, Jarvis D (2012) Low carbon mobility: opportunities and challenges for local economic development. Local Econ 27:689-691

Boulter PG, McCrae IS, Barlow TJ (2007) A review of instantaneous emission models for road vehicles. Transport Research Laboratory (TRL), Wokingham 
Boulter PG, Barlow TJ, McCrae IS (2009) Emissions factors 2009: report 3-exhaust emission factors for road vehicles in the United Kingdom. Wokingham, TRL Limited

Brand C (2005) Integrated travel emissions profiles: methodology report. Transport studies unit and environmental change institute. University of Oxford, Oxford

Brand C, Boardman B (2008) Taming of the few-the unequal distribution of greenhouse gas emissions from personal travel in the UK. Energy Policy 36:224-238

Brand C, Preston J (2010) 60-20 emission-the unequal distribution of green house gas emissions from personal, non-business travel in the UK. Transp Policy 17:9-19

Brand C, Goodman A, Rutter H, Song Y, Ogilvie D (2013) Associations of individual, household and environmental characteristics with carbon dioxide emissions from motorised passenger travel. Appl Energy 104:158-169

Burchardt T, Grand JL, Piachaud D (1999) Social exclusion in Britain 1991-1995. Soc Policy Adm 33:227-244

Burchardt T, Grand JL, Piachaud D (2002) Degrees of exclusion: developing a dynamic, multi-dimensional measure. In: Hills J, Grand JL, Piachaud D (eds) Understanding social exclusion. Oxford University Press, Oxford, pp 30-43

Cass N, Shove E, Urry J (2005) Social exclusion, mobility and access. Soc Rev 53:539-555

Chapman L (2007) Transport and climate change: a review. J Transp Geogr 15:354-367

Church A, Frost M, Sullivan K (2000) Transport and social exclusion in London. Transp Policy 7:195-205

Committee on Climate Change (2008) Building a low-carbon economy - the Uk's contribution totackling climate change

Committee on Climate Change (2010) The fourth carbon budget: reducing emissions through the 2020 s

Currie G, Stanley J (2008) Investigating links between social capital and public transport. Transp Rev 28:529-547

Currie G, Richardson T, Smyth P, Vella-Brodrick D, Hine J, Lucas K, Stanley J, Morris J, Kinnear R, Stanley J (2009) Investigating links between transport disadvantage, social exclusion and wellbeing in Melbourne-preliminary results. Transp Policy 16:97-105

Darido G, Torres-Montoya M, Mehndiratta S (2014) Urban transport and $\mathrm{CO}_{2}$ emissions: some evidence from Chinese cities. Wiley Interdiscip Rev Energy Environ 3:122-155

DEFRA (2008) A framework for pro-environmental behaviours. DEFRA, London

Department for Communities and Local Government (2008) The English indices of deprivation 2007. Department for Communities and Local Government (DCLG), London

Department for Regional Development (2001) Shaping our future: regional development strategy for Northern Ireland 2025. Department for Regional Development, Belfast

Department for Regional Development (2002) Regional Transportation strategy for Northern Ireland 2002-2012. Department for Regional Development, Belfast

Department for Regional Development (2005) Planning policy statement 13 (PPS 13): transportation and land use. Department for Regional Development, Belfast

Department for Regional Development (2008) Travel survey for Northern Ireland 2005-2007. Department for Regional Development, Belfast

Department for Regional Development (2010) Northern Ireland transport statistics 2009-10. Department for Regional Development, Belfast

Department for Transport (2004) Smarter choices—changing the way we travel. Department for Transport, London
Department for Transport (2006) Social inclusion: transport aspects (final report). Department for Transport, London

Department for Transport (2009) Delivering sustainable low carbon travel: an essential guide for local authorities. Department for Transport, London

Department for Transport (2010a) ENV0202 carbon dioxide emissions by transport mode: United Kingdom, 1998-2008. Department for Transport, London

Department for Transport (2010b) The effects of smarter choice programmes in the sustainable travel towns: summary report. Department for Transport, London

Department for Transport (2011) Creating growth, cutting carbon: making sustainable local transport happen. Department for Transport, London

Department for Transport, Greater Manchester Passenger Transport Executive (2004) Intermode: innovations in demand responsive transport. Department for Transport and Greater Manchester Passenger Transport Executive

Department of the Environment Transport and the Region (1998) A new deal for transport: better for everyone. Department of the Environment Transport and the Region, London

Druckman A, Jackson T (2008) Household energy consumption in the UK: a highly geographically and socio-economically disaggregated model. Energy Policy 36:3177-3192

Farrington J, Gray D, Martin S, Roberts D (1998) Car dependence in rural Scotland. The Scottish Office Central Research Unit, Edinburgh

Fawcett T (2010) Personal carbon trading: a policy ahead of its time? Energy Policy 38:6868-6876

Frank LD, Brian SJ, Bachman W (2000) Linking land use with household vehicle emissions in the central puget sound: methodological framework and findings. Transp Res Part D 5:173-196

Fudge S, Peters M (2011) Behaviour change in the UK climate debate: an assessment of responsibility, agency and political dimensions. Sustainability 3:789-808

Garren SJ, Pinjari AR, Brinkmann R (2011) Carbon dioxide emission trends in cars and light trucks: a comparative analysis of emissions and methodologies for Florida's counties (2000 and 2008). Energy Policy 39:5287-5295

Glaeser EL, Kahn ME (2010) The greenness of cities: carbon dioxide emissions and urban development. J Urban Econ 67:404-418

Gough IAN (2013) Carbon Mitigation Policies, Distributional Dilemmas and Social Policies. J Soc Policy 42:191-213

Gray D, Shaw J, Farrington J (2006) Community transport, social capital and social exclusion in rural areas. Area 38:89-98

HM Government (2005) Securing the future: the UK government sustainable development strategy. HMSO. http://collections. europarchive.org/tna/20080530153425/http://www.sustainabledevelopment.gov.uk/publications/pdf/strategy/SecFut_complete. pdf 20 Nov 2014

Higgs G, White S (2000) Alternatives to census-based indicators of social disadvantage in rural communities. Prog Plan 53:1-81

Hine J, Mitchell F (2001) The role of transport in social exclusion in urban Scotland. Scottish Executive Central Research Unit, Edinburgh

Hine J, Mitchell F (2003) Transport disadvantage and social exclusion: exclusionary mechanisms in transport in urban Scotland. Ashgate, Hampshire

Hine J, Kamruzzaman M, Blair N (2012) Weekly activity-travel behaviour in rural Northern Ireland: differences by context and socio-demographic. Transportation 39:175-195

Hodge I, Dunn J, Monk S, Fitsgerald M (2002) Barriers to participation in residual rural labour markets. Work Employ Soc 16:457-476 
Howarth CC, Polyviou P (2012) Sustainable travel behaviour and the widespread impacts on the local economy. Local Econ 27:764-781

Jones A, Goodman A, Roberts H, Steinbach R, Green J (2013) Entitlement to concessionary public transport and wellbeing: a qualitative study of young people and older citizens in London, UK. Soc Sci Med 91:202-209

Joumard R, Andre M (1990) Cold start emissions of traffic. Sci Total Environ 93:175-182

Kamruzzaman M, Hine J (2011) Participation index: a measure to identify rural transport disadvantage? J Transp Geogr 19:882-899

Kelly JA, Ryan L, Casey E, O'Riordan N (2009) Profiling road transport activity: emissions from 2000 to 2005 in Ireland using national car test data. Transp Policy 16:183-192

Kennedy C (2010) Methodology for inventorying greenhouse gas emissions from global cities. Energy Policy 38:4828-4837

Ketelaer T, Kaschub T, Jochem P, Fichtner W (2014) The potential of carbon dioxide emission reductions in German commercial transport by electric vehicles. Int $\mathrm{J}$ Environ Sci Technol $11: 2169-2184$

Kilby K, Smith N (2012) Accessibility planning policy: evaluation and future direction-final report. Department for Transport, London

Knowles RD (2006) Transport shaping space: differential collapse in time and space. J Transp Geogr 14:407-425

Ko J, Park D, Lim H, Hwang IC (2011) Who produces the most $\mathrm{CO}_{2}$ emissions for trips in the Seoul metropolis area? Transp Res Part D Transp Environ 16:358-364

Kok R, Annema JA, van Wee B (2011) Cost-effectiveness of greenhouse gas mitigation in transport: a review of methodological approaches and their impact. Energy Policy 39:7776-7793

Li J (2011) Decoupling urban transport from GHG emissions in Indian cities-a critical review and perspectives. Energy Policy 39:3503-3514

Loo BPY, Li L (2012) Carbon dioxide emissions from passenger transport in China since 1949: implications for developing sustainable transport. Energy Policy 50:464-476

Lucas K (2006) Providing transport for social inclusion within a framework for environmental justice in the UK. Transp Res Part A 40:801-809

Lucas K, Jones P (2012) Social impacts and equity issues in transport: an introduction. J Transp Geogr 21:1-3

Marques AC, Fuinhas JA, Gonçalves BM (2012) Dieselization and road transport $\mathrm{CO}_{2}$ emissions: evidence from Europe. Low Carbon Econ 3:54-62

Mathez A, Manaugh K, Chakour V, El-Geneidy A, Hatzopoulou M (2013) How can we alter our carbon footprint? Estimating GHG emissions based on travel survey information. Transportation 40:131-149

McDonagh J (2006) Transport policy instruments and transportrelated social exclusion in rural Republic of Ireland. J Transp Geogr 14:355-366

McNamara D, Caulfield B (2011) Measuring the potential implications of introducing a cap and share scheme in Ireland to reduce green house gas emissions. Transp Policy 18:579-586

Meyer I, Leimbach M, Jaeger CC (2007) International passenger transport and climate change: a sector analysis in car demand and associated $\mathrm{CO}_{2}$ emissions from 2000 to 2050. Energy Policy 35:6332-6345

Moseley MA (1979) Accessibility: the rural challenge. Methuen, London

NISRA (2001) Population and Migration. Northern Ireland Statistics and Research Agency (NISRA). http://www.nisranew.nisra.gov. uk/census/start.html. Accessed 3 Mar 2009
NISRA (2005) The Northern Ireland multiple deprivation measure. Northern Ireland Statistics and Research Authority. http://www. nisra.gov.uk. Accessed 16 May 2008

Nocera S, Maino F, Cavallaro F (2012) A heuristic method for determining $\mathrm{CO}_{2}$ efficiency in transportation planning. Eur Transp Res Rev 4:91-106

Northern Ireland Assembly (2011) Report on the committee's inquiry into sustainable transport. Committee for Regional Development, Belfast

Ntziachristos L, Samaras Z (2009) COPERT: EMEP/EEA emission inventory guidebook 2009. European Environment Agency

Nutley S (1985) Planning options for the improvement of rural accessibility: use of the time-space approach. Reg Stud 19:37-50

Nutley S (1996) Rural transport problems and non-car populations in the USA. J Transp Geogr 4:93-106

O' Mahony T, Zhou P, Sweeney J (2012) The driving forces of change in energy-related $\mathrm{CO}_{2}$ emissions in Ireland: a multisectoral decomposition from 1990 to 2007. Energy Policy 44:256-267

Rassafi AA, Vaziri M (2005) Sustainable transport indicators: definition and integration. Int J Environ Sci Technol 2:83-96

Santos G, Behrendt H, Teytelboym A (2010) Part II: policy instruments for sustainable road transport. Res Transp Econ 28:46-91

Schipper L (2011) Automobile use, fuel economy and $\mathrm{CO}_{2}$ emissions in industrialized countries: encouraging trends through 2008 ? Transp Policy 18:358-372

Scottish Executive (2006) Scottish index of multiple deprivation 2006: General report. Scottish executive. http://www.scotland. gov.uk/Resource/Doc/151578/0040731.pdf. Accessed 18 Dec 2008

Shergold I, Parkhurst G (2012) Transport-related social exclusion amongst older people in rural Southwest England and Wales. J Rural Stud 28:412-421

Shucksmith M, Chapman P (1998) Rural development and social exclusion. Soc Rural 38:225-242

Shucksmith M, Philip L (2000) Social exclusion in rural areas: a literature review and conceptual framework. The Scottish Executive Central Research Unit, Edinburgh

Simpson BJ (2006) Reducing carbon dioxide emissions from UK road transport. In: Proceedings of the ICE-municipal engineer, pp 203-210

Social Exclusion Unit (2003) Making the connections: transport and social exclusion. Social Exclusion Unit, The Stationery Office, London

Solomon S, Plattner G-K, Knutti R, Friedlingstein P (2009) Irreversible climate change due to carbon dioxide emissions. Environ Sci 106:1704-1709

Tchepel O, Dias D, Ferreira J, Tavares R, Isabel Miranda A, Borrego C (2012) Emission modelling of hazardous air pollutants from road transport at urban scale. Transport 27:299-306

Tian X, Chang M, Tanikawa H, Shi F, Imura H (2012) Regional disparity in carbon dioxide emissions. J Ind Ecol 16:612-622

Torres M, Pinho P (2011) Encouraging low carbon policies through a local emissions trading scheme (LETS). Cities 28:576-582

Wadud Z, Noland RB, Graham DJ (2008) Equity analysis of personal tradable carbon permits for the road transport sector. Environ Sci Policy 11:533-544

Wang Y, Hayashi Y, Chen J, Li Q (2014) Changing urban form and transport $\mathrm{CO}_{2}$ emissions: an empirical analysis of Beijing, China. Sustainability 6:4558-4579 
Wells P (2012) Converging transport policy, industrial policy and environmental policy: the implications for localities and social equity. Local Econ 27:749-763

Welsh Assembly Government (2008) Welsh index of multiple deprivation 2008 (WIMD) — summary report. Welsh assembly government. http://wales.gov.uk/topics/statistics/publications/ wimd08sum/?lang=en. Accessed 18 Dec 2008
Xing Y, Handy SL, Mokhtarian PL (2010) Factors associated with proportions and miles of bicycling for transportation and recreation in six small US cities. Transp Res Part D 15:73-81

Yigitcanlar T, Kamruzzaman M (2014) Investigating the interplay between transport, land use and the environment: a review of the literature. Int J Environ Sci Technol 11:2121-2132 